\title{
Pengaruh Temperatur, Konsentrasi Katalis Dan Rasio Molar Metanol- Minyak Terhadap Yield Biodisel Dari Minyak Goreng Bekas Melalui Proses Netralisasi-Transesterifikasi
}

\author{
Antonius Prihanto dan T. A. Bambang Irawan \\ Program Studi D3 Teknik Kimia \\ Akademi Kimia Industri Santo Paulus Semarang \\ Jl. Pleburan Barat No.11 A, Pleburan, Semarang Selatan, Kota Semarang, Jawa Tengah 50241 \\ Email : antoniusprihanto@ymail.com
}

\begin{abstract}
Abstrak
Telah dilakukan penelitian tentang pembuatan biodisel dari minyak goreng bekas melalui proses netralisasitransesterifikasi. Tujuan penelitian ini adalah untuk mengkaji pengaruh temperatur terhadap yield biodiesel, pengaruh konsentrasi katalis terhadap yield biodiesel dan pengaruh rasio molar methanol-minyak goreng bekas terhadap yield biodiesel melalui proses netralisasi dan transesterifikasi. Untuk mendapatkan kondisi proses transesterifikasi terbaik, maka dikaji pengaruh variasi suhu $\left(30^{\circ} \mathrm{C}, 40^{\circ} \mathrm{C}, 50^{\circ} \mathrm{C}, 60^{\circ} \mathrm{C}, 70{ }^{\circ} \mathrm{C}\right)$, variasi konsentrasi katalis $\mathrm{KOH}(0,75 \%, 1 \%, 1,25 \%, 1,5 \%, 1,75 \%)$ dan rasio molar metanol-minyak (6:1; 7:1; 8:1; 9:1; 10:1) terhadap yield biodiesel yang dihasilkan dari minyak goreng bekas. Hasil penelitian menunjukkan pada rasio $6: 1$, konsentrasi katalis $\mathrm{KOH} 1 \%$ pada suhu $60^{\circ} \mathrm{C}$ mengahasilkan yield biodiesel maksimal sebesar $87,3 \%$.
\end{abstract}

Kata kunci : biodiesel, minyak goreng bekas, yield biodisel, netralisasi-transesterifikasi

\begin{abstract}
Effect of Temperature, Catalyst Concentration and Methanol-Oil Molar Ratio Against Biodiesel Yield from Used Cooking Oil Through Neutralization Transesterification Process
\end{abstract}

A research has been conducted on the making of biodiesel from used cooking oil through a neutralizationtransesterification process. The purpose of this study was to examine the effect of temperature on biodiesel yield, the effect of catalyst concentration on biodiesel yield and the effect of molar ratio of methanol to used biodiesel yield through neutralization and transesterification process. To obtain the best transesterification process condition, the effect of temperature variation ( $30 \mathrm{oC}, 40 \mathrm{oC}, 50 \mathrm{oC}, 60 \mathrm{oC}, 70 \mathrm{oC}), \mathrm{KOH}$ catalyst concentration variation $(0.75 \%, 1 \%, 1.25 \%, 1,5 \%, 1.75 \%)$ and the molar ratio of methanol-oil $(6: 1 ; 7: 1 ; 8: 1 ; 9$ : 1; 10: 1) to the yield of biodiesel produced from used cooking oil. The results showed at a ratio of 6: 1, the concentration of $1 \% \mathrm{KOH}$ catalyst at $60^{\circ} \mathrm{C}$ resulted in a maximum biodiesel yield of $87.3 \%$.

Keywords: biodiesel, used cooking oil, biodisel yield, neutralization-transesterification

\section{PENDAHULUAN}

Satu decade terakir konsumsi minyak bumi sudah melewati kemampuan produksi minyak bumi dalam negri. Kusus solar hingga tahun 2025 akan mengalami defisit 35 juta kilo liter. Eksploitasi besar besaran dari bahan bakar minyak ini akan mempercepat menipisnya hingga habisnya bahan bakar minyak bumi. Menurut Bustomi et al. (2008) biodiesel adalah bahan bakar 
alternatif yang dapat mengurangi ketergantungan akan kebutuhan bahan bakar minyak bumi. Dengan menurunnya tingkat ketergantungan kebutuhan bakar minyak bumi diharapkan dapat memperlambat menipisnya cadangan minyak bumi.

Bahan baku utama pembuatan biodiesel adalah semua minyak nabati yang merupakan sumber energy terbarukan. Sudah banyak penelitian biodiesel dari minyak goreng. Minyak goreng sudah telah terbukti dapat dimanfaatkan sebagai bahan baku pembuatan biodiesel. Dari beberapa penelitian yang telah dilakukan menunjukkan bahwa biodiesel dari minyak goreng telah memenuhi sayarat SNI sebagai bahan bakar mesin disel (Herizal, 2008 ; Kanzedo et al., 2008). Pemanfaatan minyak goreng sebagai bahan baku pembuatan biodiesel tentu akan menimbulkan permasalahan baru karena akan bersaing dengan kebutuhan pangan. Pemanfaatan minyak goreng bekas sebagai bahan baku pembuatan biodiesel tidak akan menimbulkan permasalahan baru karena tidak bersaing dengan kebutuhan pangan. Pemanfaatan minyak goreng bekas sebagai bahan baku pembuatan biodiesel justru akan mendorong masyarakat untuk tidak memanfaatkan minyak goreng bekas sebagai konsumsi pangan sehingga pola hidup masyarakat menjadi lebih sehat. Pemanfaatan minyak goreng bekas yang merupakan limbah dari proses penggorengan sebagai bahan baku biodiesel juga akan meningkatkan nilai ekonomis minyak goreng bekas.

Berbagai metode telah dikembangkan untuk membuat biodiesel dari minyak nabati kususnya minyak goreng bekas. Pembuatan biodiesel dengan proses perengkahan non katalis catalytic cracking telah dilakukan Buchori dan Widayat (2007). Metode ini berlangsung pada suhu dan tekanan yang tinggi sehingga membutuhkan energy yang besar dan peralatan yang mahal. Pembuatan biodiesel dari minyak jelantah menggunakan proses enzimatis telah dilakukan dilakukan Saifuddin, et al. (2009). Metode enzimatis ini memerlukan biaya produksi yang tinggi dan waktu reaksi yang lama, sehingga membuat biodiesel dengan metode ini kurang menguntungkan. Proses yang paling umum dilakukan untuk membuat biodiesel dari minyak nabati adalah melalui proses transesterifikasi, karena metode ini memerlukan alat yang sederhana dan waktu proses yang lebih singkat.

Minyak jelantah umumnya memiliki kandungan asam lemak bebas yang tinggi. Menurut Hambali et al. (2008) transesterifikasi dari minyak nabati yang memiliki asam lemak bebas yang cukup tinggi akan terjadi blocking reaksi pembentukan biodiesel. Terjadinya blocking reaksi akan mengakibatkan methanol yang seharusnya bereaksi dengan trigliserida terhalang oleh reaksi pembentukan sabun, sehingga konsumsi methanol naik dua kali lipat. Blocking reaksi juga mengakibatkan kebutuhan katalis meningkat. Pemisahkan biodiesel dengan gliserol juga sulit akibat terbentuknya sabun sehingga rendemen yang dihasilkan menurun. Sulitnya pemisahan produk juga dapat mengurangi kualitas biodiesel yang dihasilkan.

Menurut Hambali et al. (2008) untuk mengurangi jumlah asam lemak bebas dalam minyak nabati dapat dilakukan melalui proses esterifikasi. Menggunakan proses esterifikasi sebelum transesterifikasi akan menambah waktu proses lebih lama dan kebutuhan methanol menjadi lebih banyak, karena proses esterifikasi juga akan membutuhkan methanol berlebih untuk dapat mengkonversi asam lemak bebas menjadi biodiesel. Pembuatan biodiesel dari minyak goreng bekas melalui proses esterifikasi dan transesterifikasi tidaklah efisien waktu dan biaya (Ramadhas, 2004).

Metode netralisasi dengan menggunakan larutan $\mathrm{NaOH}$ dapat menghilangkan asam lemak bebas sehingga minyak goreng bekas menjadi lebih murni. Pembuatan biodiesel dari minyak goreng bekas melalui proses netralisasi transesterifikasi diharapkan diharapkan lebih efisien dari sisi waktu dan biaya.

\section{METODOLOGI}

\section{Alat dan Bahan}

Alat utama yang digunakan penelitian ini meliputi hotplate dengan magnetik stirrer, vacuum rotary evaporator labu leher tiga, pendingin bola, corong pisah. Dan alat pendukung analisa bahan baku antara lain gelas piala, erlenmeyer, gelas ukur, labu takar dan buret. Bahan utama pembuatan biodiesel dalam penelitian ini adalah minyak goreng bekas dan methanol. Sedangkan 
bahan bahan pendukung lainnya adalah $\mathrm{KOH}$, $\mathrm{NaOH}, \mathrm{H}_{3} \mathrm{PO}_{4}$.

\section{Prosedur Penelitian}

\section{Netralisasi}

Tigaratus $\mathrm{ml}$ minyak goreng bekas yang telah disaring, dipanaskan pada suhu $60{ }^{\circ} \mathrm{C}$. Minyak ditambah $13,4 \mathrm{ml}$ larutan $\mathrm{NaOH} 20{ }^{\circ} \mathrm{Be}$ dan diaduk selama 2 menit. Hasil dari proses ini selanjutnya dipindahkan ke dalam corong pisah dan ditambah air hangat $\left(70{ }^{\circ} \mathrm{C}\right)$ sebanyak $10 \%$ dari volume minyak dan dibiarkan hingga minyak dan air dapat dipisahkan. Proses pencucian diulang ulang hingga air cucian netral. Minyak yang telah dicuci selanjutnya dikeringkan dengan menggunakan vacuum rotary evaporator pada suhu $85^{\circ} \mathrm{C}$ selama 30 menit.

\section{Transesterifikasi}

Duaratus $\mathrm{ml}$ (183,19 gram) minyak goreng bekas hasil netralisasi dimasukkan ke dalam labu leher tiga dan dipanaskan dengan hotplate hingga mencapai suhu $60{ }^{\circ} \mathrm{C}$. Larutan metanolik- $\mathrm{KOH}$ yang telah ditetapkan ditambahkan ke dalam minyak dan magnetic stirrer dihidupkan dengan kecepatan $500 \mathrm{rpm}$. Proses transesterifikasi ini dilakukan selama 60 menit.

\section{Pemisahan Produk}

Hasil proses transesterifikasi dipindahkan ke dalam corong pisah dan dibiarkan kira kira 12 jam (semalam). Setelah semalam campuran akan membentuk 2 lapisan. Lapisan atas jernih kekuningan merupakan produk biodiesel (metil ester) dan lapisan bawah berwarna gelap adalah gliserol. Selanjutnya lapisan bawah di buang, dan lapisan bagian atas yang merupakan produk metil ester (biodisel) diambil.

\section{Pencucian Produk}

Setelah produk biodiesel dipisahkan dari gliserol, dilakukan pencucian terhadap biodisel untuk mendapatkan produk biodiesel (metil ester) yang murni. Produk biodiesel ini dicuci dengan air hangat $\left( \pm 60^{\circ} \mathrm{C}\right)$ yang mengandung asam acetat $0,01 \%$. Pencucian dilanjutkan dengan menggunakan air hangat hingga air cucian menjadi netral.

\section{Pengeringan Produk}

Setelah metil ester dicuci, selanjutnya harus dikeringkan untuk menghilangkan sisa sisa air setelah pencucian. Pada penelitian ini pengeringan biodiesel dilakukan dengan menggunakan vacuum rotary evaporator pada suhu $85^{\circ} \mathrm{C}$ selama 30 menit.

\section{Penentuan Yield Biodisel}

Respon yang diamati dalam penelitian ini adalah yield biodiesel yang terbentuk dari reaksi transesterifikasi. Yield biodisel ditentukan dengan menggunakan rumus:

$$
\text { Yield }=\frac{\text { berat biodisel }}{\text { berat minyak goreng bekas }} \times 100 \%
$$

Berat biodisel merupakan berat metil ester yang dihasilkan dari proses transesterifikasi. Sedangkan berat minyak goreng bekas adalah berat minyak goreng bekas yang telah dimurnikan melalui proses netralisasi.

\section{HASIL DAN PEMBAHASAN}

\section{Pengaruh Suhu terhadap Yield Biodisel}

Peningkatan suhu reaksi akan meningkatkan energi kinetik dari reaktan sehingga akan meningkatkan jumlah minyak yang terkonversi menjadi biodiesel. Semakin besar minyak yang terkonversi menjadi biodiesel berarti biodiesel yang dihasilkan semakin banyak sehingga yield biodiesel juga meningkat. Pengaruh suhu transesterifikasi pada pembuatan biodiesel dari minyak jelantah terhadap yield biodiesel telah diuji pada rasio molar methanolminyak $6: 1 ; 7: 1$ dan $8: 1$ dengan konsentrasi katalis $\mathrm{KOH} 1 \%$.

Pada Gambar 1. Terlihat bahwa bila suhu reaksi transesterifikasi dinaikkan, yield biodisel yang dihasilkan akan semakin meningkat. Fakta ini sesuai dengan pendapat Leung et al. (2010) yang menyatakan bahwa naiknya suhu reaksi akan menurunkan viskositas minyak sehingga laju reaksi akan meningkat. Meningkatnya suhu reaksi juga dapat meningkatkan jumlah tumbukkan efektif untuk menghasilkan reaksi sehingga biodisel yang dihasilkan juga meningkat (Prihanto et al.., 2013). Suhu terbaik pada reaksi transesterifikasi untuk menghasilkan yield biodisel 
maksimal adalah pada suhu $60{ }^{\circ} \mathrm{C}$ pada rsio methanol-minyak $6: 1 ; 7: 1$ dan $8: 1$. Pada ke tiga rasio molar metanol-minyak ketika suhu dtingkatkan hingga suhu $60{ }^{\circ} \mathrm{C}$ mengalami peningkatan yield biodisel relatif sama.

Bila suhu ini ditingkatkan lagi hingga 70 ${ }^{\circ} \mathrm{C}$, ternyata yield biodisel yang dihasilkan justru akan menurun. Penurunan ini terjadi pada ketiga rasio molar $6: 1 ; 7: 1$ dan $8: 1$. Pada suhu $70{ }^{\circ} \mathrm{C}$ telah melewati titik didih metanol, sehingga sebagian metanol mengalami perubahan fasa dari cair menjadi gas. Terjadinya perubahan fasa metanol ini menyebabkan jumlah metanol dalam fasa cair berkurang. Berkurangnya jumlah metanol dalam larutan menyebabkan berkurangnya jumlah tumbukan efektif untuk menghasilkan biodisel sehingga yield bidisel yang terbentuk akan berkurang (Prihanto et al., 2013).

Penurunan yield biodisel pada ke tiga rasio molar metanol-minyak tidak sama. Pada rasio molar metanol-minyak $6: 1$ mengalami penurunan yang paling tajam dibanding rasio metanol-minyak $7: 1$ dan $8: 1$. Pada rasio molar 6 : 1 mengalami penurunan yiel biodisel yang lebih tajam, karena berubahnya fase cair metanol ke uap mengalami penurunan rasio molar metanolminyak pada fase cair paling tajam. Pada rasio molar $7: 1$ dan $8: 1$ turunnya rasio molar metanol-minyak karena perubahan fase metanol cair ke uap dimbangi dengan bertambahnya metanol sehingga penurunan rasio molar metanol-minyak tidak setajam pada rasio $6: 1$.

Pada rasio metanol-minyak $8: 1$ mengalami penurunan yield biodisel yang paling kecil, karena penurunan rasio molar metanol akibat perubahan fase cair ke uap diimbangi dengan penambahan metanol ( dari rasio $8: 1$ ) paling banyak sehingga penurungan rasio molar paling tidak berarti dibanding rasio $6: 1$ dan $7: 1$.

\section{Pengaruh Konsentrasi $\mathrm{KOH}$ terhadap Yield Biodisel}

Katalis berfungsi untuk meningkatkan laju reaksi. Semakin banyak jumlah katalis yang ditambahkan akan meningkatkan laju reaksi. Meningkatnya laju reaksi transesterifikasi pada waktu tertentu akan meningkatkan jumlah minyak goreng bekas yang terkonversi menjadi biodiesel. Pengaruh konsentrasi katalis $\mathrm{KOH}$ terhadap yield biodiesel yang dihasilkan pada rasio metanolminyak $6: 1 ; 7: 1$ dan $8: 1$ pada suhu $60{ }^{\circ} \mathrm{C}$ seperti yang ditunjukkan Gambar 2 .

Bila pada reaksi transesterifikasi ini konsentrasi katalis $\mathrm{KOH}$ dinaikkan daari 0,75\% menjadi $1 \%$, yield biodisel mengalami peningkatan. Semakin besar konsentrasi katalis dalam larutan, maka energi aktivasi suatu reaksi semakin kecil, sehingga produk akan semakin banyak terbentuk. Meningkatnya konsentrasi katalis meyebabkan meningkatnya yield biodisel.

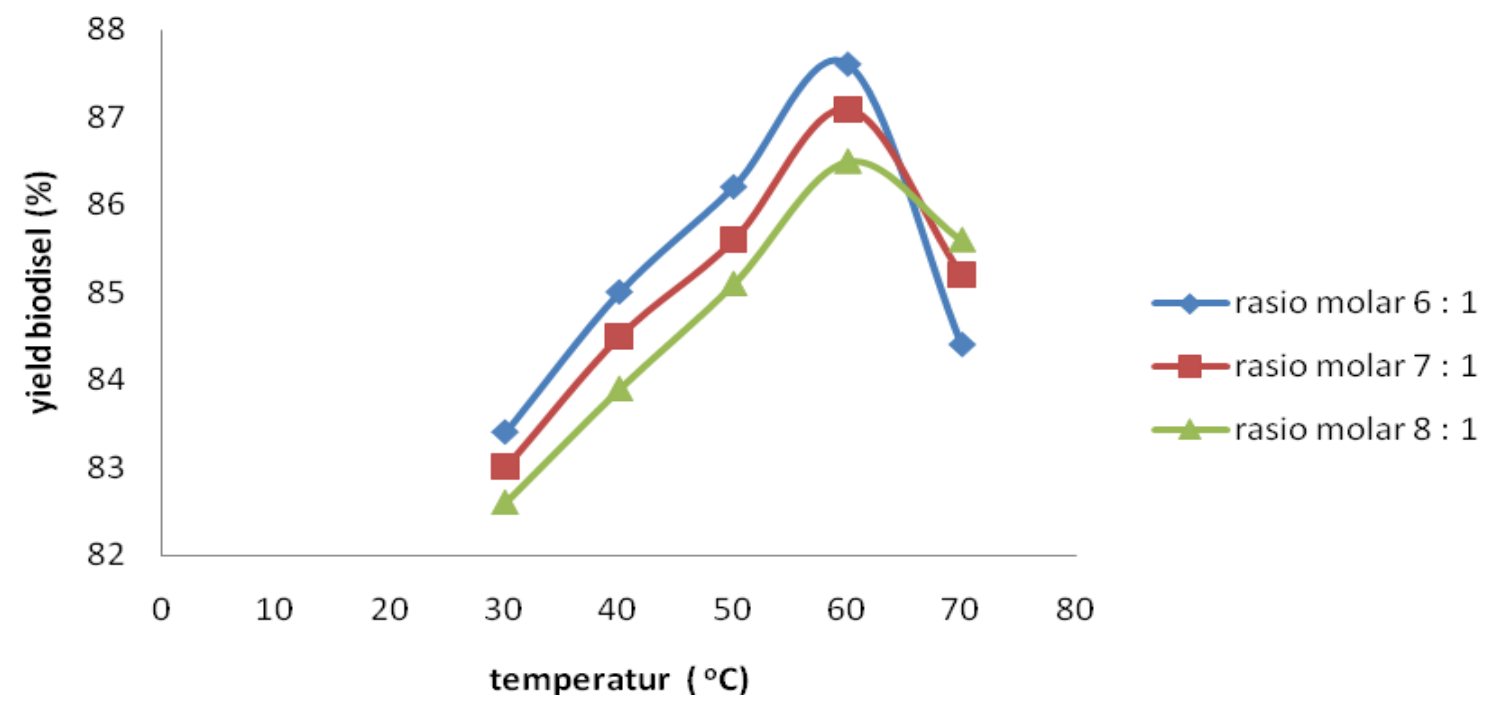

Gambar 1. Pengaruh suhu terhadap yield biodisel pada rasio molar metanol-minyak $6: 1 ; 7: 1$ dan $8: 1$ dengan konsentrasi katalis $\mathrm{KOH} 1 \%$ 
Gambar 2. menunjukkan bahwa pada konsentrasi katalis $\mathrm{KOH} \mathrm{1,0 \%} \mathrm{menghasilkan} \mathrm{yield} \mathrm{biodisel}$ maksimal sebesar 87,8 \%. Pada rasio molar metanol-minyak $6: 1$ dan $7: 1$ yield biodisel maksimal tercapai pada konsentrasi katalis 1,0\%. Pada rasio molar 8 : 1 yield biodisel maksimal justru terjadi pada konsentrasi $\mathrm{KOH} \mathrm{1,25 \%} \mathrm{hal} \mathrm{ini}$ terjadi karena bertambahnya rasio molar metanol minyak akan menurunkan konsentrasi $\mathrm{KOH}$ dan penurunan paling besar adalah pada rasio metanol-minyak 8 : 1. Pada konsentrasi $\mathrm{KOH} \mathrm{1,25}$ $\%$ penurunan konsentrasi $\mathrm{KOH}$ diimbang dengan bertambahnya konsentrasi katalis $\mathrm{KOH}$ sehingga pada rasio molar 8 : 1 konsentrasi $\mathrm{KOH} \mathrm{1,25 \%}$ adalah keadaan konsentrasi $\mathrm{KOH}$ optimal untuk menghasilkan yield biodisel maksimal.

Bila konsentrasi katalis $\mathrm{KOH}$ ini terus ditingkatkan hingga 1,75 \%, yield biodisel yang terbentuk justru akan terus menurun. Hal ini terjadi karena penambahan konsentrasi katalis yang berlebihan, mendorong reaksi terbentuknya sabun (Hingu et al., 2010; Koh et al., 2011;"Wang et al., 2012). Penurunan paling tajam terjadi pada rasio molar metanol-minyak $6: 1$ dibanding rasio $7: 1$ dan rasio $8: 1$ karena pada rasio $6: 1$ volume metanol paling kecil. Pada kondisi ini mengakibatkan konsentrasi $\mathrm{KOH}$ paling besar sehingga pada rasio $6: 1$ terjadi pembentukan sabun paling besar sehingga mengalami penurunan yield biodisel paling tajam. Sementara pada rasio metanol-minyak $8: 1$ konsentrasi $\mathrm{KOH}$ mengalami kenaikan paling kecil sehingga pembentukan sabun mengalami kenaikan paling kecil sehingga pada rasio ini penurunan yield biodisel tidak begitu tajam.

\section{Pengaruh Rasio Molar Metanol-Minyak}

Peningkatan rasio molar methanol-minyak secara teori akan meningkatkan yield biodiesel. Meningkatnya jumlah methanol dalam minyak akan menggeser reaksi kearah kanan atau kearah produk sehingga akan meningkatkan yield biodiesel. Hasil penelitian pengaruh rasio molar metanol-minyak terhadap yield biodisel pada suhu $60{ }^{\circ} \mathrm{C}$ dengan konsentrasi katalis $\mathrm{KOH} 1 \%$, $\mathrm{KOH} 1,25 \%$ dan $\mathrm{KOH} 1,5 \%$ seperti yang ditunjukkan Gambar 3.

Pada Gambar 3. menunjukkan bahwa, bila rasio metanol-minyak ditingkatkan yield biodisel yang dihasilkan justru akan terus menurun baik pada konsentrasi $\mathrm{KOH} 1 \%, 1,25 \%$ dan 1,5\%. Yield biodisel maksimal dicapai pada rasio molar metanol-minyak 6:1 yaitu sebesar 87,3 \%. Penambahan rasio metanol-minyak diatas $6: 1$ ternyata justru menurunkan yield biodisel. Penambahan metanol diatas rasio 6:1 akan menurunkan konsentrasi katalis dalam larutan (Mendow et al., 2011). Menurunnya konsentrasi katalis dalam larutan akan mengurangi jumlah metoksida yang menyerang trigliserida sehingga jumlah biodisel yang dihasilkan akan berkurang. Penurunan yield biodiesel pada penggunaan

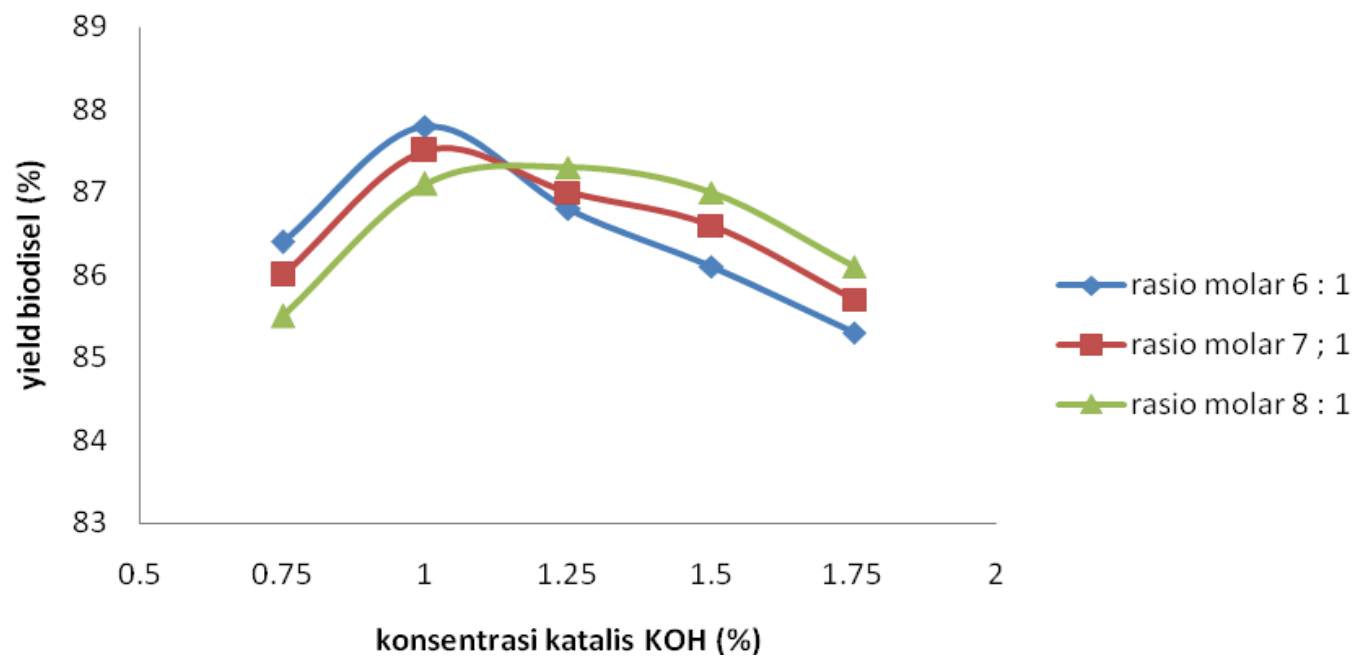

Gambar 2. Pengaruh konsentrasi katalis terhadap yield biodisel pada rasio molar metanol-minyak $6: 1 ; 7: 1$ dan $8: 1$ pada suhu $60^{\circ} \mathrm{C}$. 


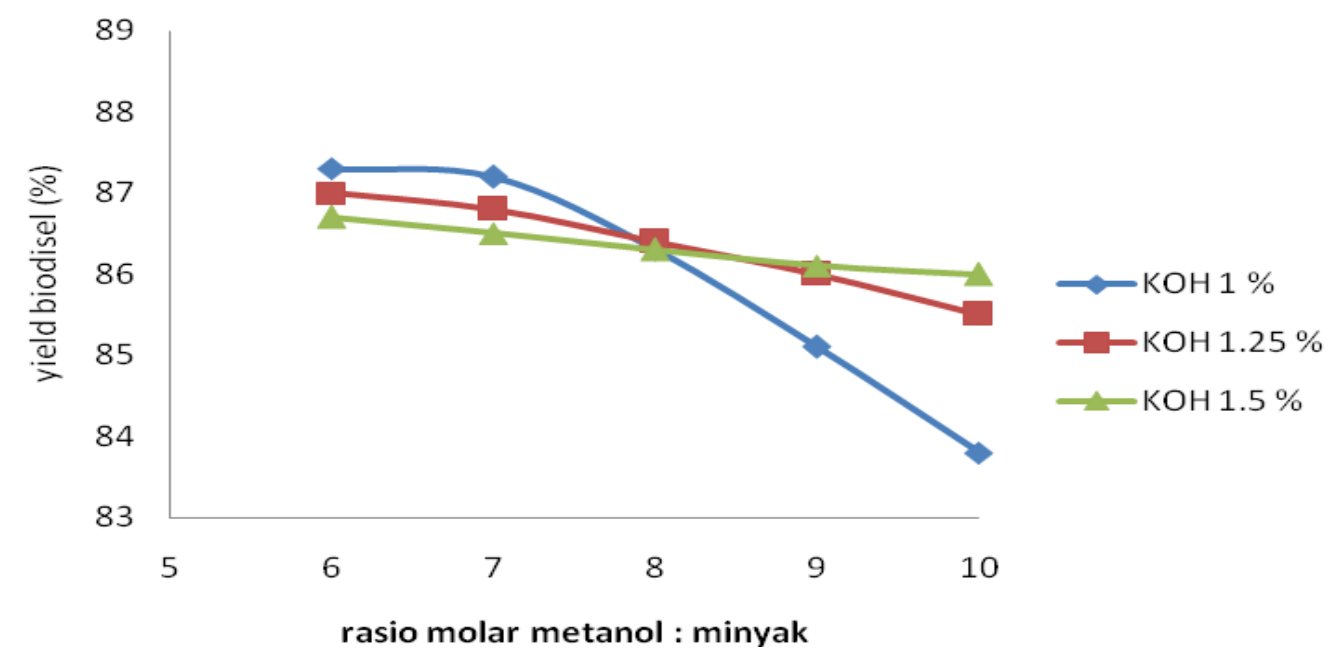

Gambar 3. Pengaruh rasio molar metanol-minyak terhadap yield biodisel pada suhu $60{ }^{\circ} \mathrm{C}$ pada konsentrasi katalis $\mathrm{KOH} 1,0 \%, \mathrm{KOH} 1,25 \%$ dan $\mathrm{KOH} 1,5 \%$.

katalis $\mathrm{KOH} 1,0 \%, \mathrm{KOH} 1,25 \%$ dan $\mathrm{KOH} 1,5 \%$. Pada penggunaan katalis $1,0 \%$ mengalami penurunan yang paling tajam karena pada konsentrasi Katalis $1 \%$ ini mengalami penurunan konsentrasi katalis paling tajam. Pada konsentrasi katalis $1,5 \%$ penurunan yield biodiesel tidak begitu signifikan, karena penurunan konsentrasi katalis karena bertambahnya methanol diimbangi dengam bertambahnya jumlah katalis $\mathrm{KOH}$ sehingga penurunan konsentrasi katalis pada $\mathrm{KOH}$ $1,5 \%$ tidak begitu berarti.

\section{KESIMPULAN}

Pembuatan biodisel dari minyak goreng bekas melalui proses netralisasi-transesterifikasi mampu mengahasilkan yield biodiesel 87,3 \%. Kondisi terbaik pembuatan biodiesel dari minyak goreng bekas melalui proses NetralisasiTransesterifi adalah pada suhu $60{ }^{\circ} \mathrm{C}$, konsentrasi katalis $\mathrm{KOH} 1,0 \%$ dan rasio molar methanolminyak $6: 1$. Pada kondisi ini yield biodiesel yang dihasilkan sebesar $87,3 \%$.

\section{DAFTAR PUSTAKA}

Bustomi, S., Tati R.T., Sudradjat, R., Leksono, B., Kosasih, S., Anggraeni, I., Syamsuwida, D., Lisnawati, Y., Mile, Y., Djaenudin, D., Mahfudz, \& Rachman, E. 2008. Nyamplung (Calophyllum inophyllum L.) Sumber Energi
Biofuel yang Potensial. Jakarta: Badan Litbang Kehutanan.

Buchori, L \& Widayat, W. 2007. Pembuatan Biodisel dari Minyak Goreng Bekas dengan Proses Catalityc Cracking. Teknik. 28:83 -93

Hambali, E., Mujdalipah, S., Tambunan, A.H., Pattiwiri, A.W. \& Hendroko, R. 2007. Teknologi Biodisel. Jakarta: PT. Agro Media Pustaka.

Herizal \& Rahman, M. 2008. Optimalisasi Transesterifikasi Minyak Kelapa Sawit Menjadi Biodisel dengan Katalis $\mathrm{NaOH}$. Lembaran Publikasi Lemigas. 42:61 - 66

Hingu, S.M., Gogate, P.R., Rathod, V.K. 2010. Synthesis of from Waste Cooking Oil using Sonochemical Reactors. Ultrasonics Sonochemistry. 17: 827-832

Koh, M.Y., Mohd, T.I. \& Ghazi. 2011. A Review of Production from Jatropha Curcas L. Oil. Renewable and Sustainable Energy Reviews. $15: 2240-2251$

Leung, D.Y.C., Wu, X. \& Leung, M. K. H. 2010. A review on Production Using Catalyzed Transesterification. Applied Energy 87:10831095

Mendow, N.S., Veizaga, B.S. and Sanchez, C.A. (2011). Biodisel Production by Two-Stage Transesterification with Etanol. Bioresource Technology 102: 10407-10413

Prihanto, A., Pramudono, B. \& Santosa, H. 2013. Peningkatan Yield Biodisel dari Minyak Biji 
Nyamplung Melalui Transesterifikasi Dua Tahap. Momentum. $9: 46$ - 53

Ramadhas, A.S., Jayaraj, S. \& Muraledharan, C. 2004. Biodisel Production From high FFA Rubber Seed Oil. Fuel. 84:335 - 340.

Saifuddin, N., Raziah. A.Z.and Farah, H.N. 2009, Production of Biodiesel from High Value Cooking Oil Using an Optomized Lipase
Enzyme/Acid - Catalyzed Hybrid Process, EJournal of Chemistry

Wang, R., Zhou, W.W., Hanna, M.A., Zhang, Y.P., Bhadury, P.S., Wanga, Y., Song, B.A. and Yang, S. 2012. Preparation, Optimization, and Fuel Properties from Non-Edible Feedstock, Datura stramonium L. Fuel 91: 182-186 